Revista ELectrónica de Investigación y EValuación Educativa

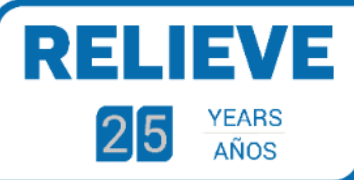

e-Journal of Educational

Research, Assessment and Evaluation

\title{
Rethinking literacy from a mixed-methods approach: Through the lens of pupils, families, and teachers in Spanish primary education
}

Volviendo a pensar la alfabetización a través de los métodos mixtos: un estudio desde la mirada de los alumnos, las familias y el profesorado en la Educación Primaria en España

\author{
Moreno-Morilla, C. (1) (iD), Guzmán-Simón, F. (2) (iD), \& García-Jiménez, E. (2) (iD) \\ (1) University of Huelva (Spain) \\ (2) University of Seville (Spain)
}

\begin{abstract}
Resumen
Los métodos mixtos presentan una alternativa sobre la investigación de la alfabetización como un fenómeno complejo. Este artículo analiza la integración de enfoques cuantitativos y cualitativos para hacer inferencias causales entre la alfabetización como práctica social y los diferentes espacios de interacción. Este estudio se realizó siguiendo un diseño secuencial de métodos mixtos. La muestra estuvo compuesta por 1.540 niños, 1.438 familias y 74 maestros. El proceso de recogida de información combinó cuestionarios y procedimientos etnográficos. Los datos se analizaron mediante la realización de análisis correlacionales, modelo de ecuaciones estructurales para grupos múltiples y análisis cualitativos comparativos. La integración aplicada en este estudio permitió identificar e interpretar las inferencias causales que existen entre las prácticas de alfabetización de estudiantes, familias y docentes que tienen lugar dentro y fuera de la escuela. Este estudio destaca la necesidad de considerar en profundidad los procesos de integración y difracción de datos cuantitativos y cualitativos en la investigación sobre alfabetización.
\end{abstract}

Palabras clave: métodos mixtos: Educación Primaria; estatus socioeconómico; prácticas de alfabetización, espacio

\begin{abstract}
A mixed-methods approach represents an alternative that allows addressing a complex phenomenon such as literacy. This paper analyses the integration of quantitative and qualitative approaches to make causal inferences between literacy as a social practice and the different interaction spaces. This study was conducted following a sequential mixed methods design. The sample comprised 1,540 children, 1,438 families, and 74 teachers. The data collection methods combined self-report questionnaires and ethnographic procedures. The data were analysed using Correlational Analysis, Structural Equation Model for Multiple-Group, and Comparative Qualitative Analysis. The integration applied in this study allowed us to identify and interpret the causal inferences that exist between the literacy practices of students, families, and teachers that take place within and outside the school. This study highlights the need to consider in depth the processes of integration and diffraction of quantitative and qualitative data in literacy research.
\end{abstract}

Keywords: mixed methods; primary education; socioeconomic status; literacy practices, space

\begin{tabular}{ll|l|ll}
\hline Received/Recibido & 2020 Mach 27 & Accepted /Aprobado 2020 November 12 & Published/Publicado & 2020 December 8 \\
\hline
\end{tabular}


Literacy practices and their social value play a key role in our society. The heterogeneous nature of current communication has transformed the way in which children develop different forms of literacy within and outside the school (Burnett, 2016; Escott \& Pahl, 2019; Gillen \& Cameron, 2010). Studies on children's literacy practices have described the complexity of its development at present (Burnett, Davies, Merchant, \& Rowsell, 2014). These studies have addressed the relationships among different literacy practices, their relationship with various everyday spaces and artefacts, and the social value that subjects ascribe to these practices (Hackett \& Somerville, 2017; Pahl, 2014). Heterogeneity in the practices of children (Mackey, 2010; Marsh, 2011), families (Duursma, Meijer, \& De Bot, 2017; Hull \& Shultz, 2002), and teachers (Hill, 2010; Hvit, 2015) develops in local and virtual spaces (Burnett, 2014). In these spaces, the child interacts with different communities outside the school (McTavish, 2014; Pahl \& Allan, 2011), within the school (Compton-Lilly \& Green, 2011; Davies \& Merchant, 2009; Gillen \& Kucirkova, 2018), in the neighbourhood (Neuman \& Celano, 2001), and on social media (Barton \& Lee, 2013; Gillen, 2014). Findings from this study have highlighted the nature of literacy as a social activity and a situated practice (Burnett \& Merchant, 2018; Mills \& Comber, 2015).

The complexity and heterogeneity of literacy processes have been approached using different methodologies. Literacy research has relied on the use of quantitative methodologies (Borrero \& Yeh, 2010; Guzmán-Simón, MorenoMorilla, \& García-Jiménez, 2018; MorenoMorilla, Guzmán-Simón, \& García-Jiménez, 2019; Poveda \& Sánchez, 2010) as well as qualitative methodologies, although the latter have prevailed, as shown by Pahl and Rowsell's (2012) and Rowsell and Pahl's (2015) review work. Mixed methods have also been used to address the study of literacy (Pellegrini \& Galda, 2003). The work that has been conducted has dealt with questions such as the importance of context in school achievement, the involvement of families and communities, and the collaboration in teams with different backgrounds. Hemmings, Beckett, Kennerly, and Yap (2013) developed a study that focused on the creation of research spaces that were shared by teams from Midwestern University (USA). These teams were made up of anthropologists/sociologists and specialists in functional literacy and second language teaching. Flecha's work (2014) concentrated on the analysis of school achievement through the empowerment of Spanish families and communities who became involved in the implementation of educational activities aimed at improving their literacy level. Sorde Marti and Mertens (2014) reflected on the use of mixed methods with at-risk groups and the concept of social justice.

This study on literacy has enabled the description of diversity and hybridism in the form of reading and writing in specific contexts. The review of these studies has allowed us to determine the lack of research that establishes causal inferences that can explain the complexity and heterogeneity of literacy processes. The construction of causal inferences has been developed from quantitative approaches. One of the adopted perspectives entails controlled intervention (using experimental designs) of one or several factors to produce certain effects (Pezoa, Mendive, \& Strasser, 2019; Woumans, Ameloot, Keuleers, \& Van Assche, 2019). The second perspective entails the establishment of dependence relationships without altering the observed conditions, preferably through the use of structural equation models and Bayesian methods (Hathcoat \& Meixner, 2017; Mahoney, Goertz, \& Ragin, 2013). Causal inferences in quantitative approaches rely on randomly selected samples of well-defined populations, tools that measure operatively defined causes and effects in a valid and reliable way, and robust statistics.

Conversely, few studies have used causal analysis within qualitative approaches. Qualitative studies make detailed descriptions of and interpretations about literacy, without establishing causal inferences. Qualitative research methodology, when grounded in single case studies, does not allow to establish similarities and differences with other cases. 
Multiple case studies favour comparison, but they do not go into depth in analysing divergences within cases (Yin, 2014). The alternative proposed by Mahoney $(1999,2000)$ for establishing causal inferences relies on a logic that combines cross-case analysis and within-case analysis. This methodological approach enables the systematic establishment of causal inferences; that is, the possibility of making attributions about literacy based on particular factors.

Finally, mixed methods also offer the possibility of establishing inferences or causal inferences (Harding \& Seefeldt, 2013). From this perspective, an inference can be defined as 'a researcher's construction of the relationships among people, events, and variables as well as his or her construction of respondents' perceptions, behaviours, and feelings and how these relate to each other in a coherent systematic manner' (Tashakkori \& Teddlie, 2003, p. 692). The construction of causal inferences in mixed-methods research requires adopting key decisions in the planning stage of an investigation. First, the subject selection methods used in qualitative and quantitative approaches must be aligned. Second, the choice of the data collection process (sequential or simultaneous) must be in accordance with the selection of subjects and must facilitate the subsequent interpretation of the data. Third, the identification and definition of effects and causes must follow a logic that allows clear traceability of the process. Finally, any effects observed in the individuals that are not explained by the causes must be made explicit and studied (Teddie \& Tashakkori, 2010).

The added value of mixed methods in our investigation lies in the integration of children's, teachers', and families' perspectives, since 'integration gives readers more confidence in the results and the conclusions they draw from the study' (McKim, 2017, p. 203). In such methods, 'the investigator collects and analyzes data, integrates the findings, and draws inferences using both qualitative and quantitative approaches or methods in a single study or a program of inquiry' (Tashakkori \& Creswell, 2007, p. 4). Nevertheless, the incorporation of perspectives on literacy brings about differences and entanglements that can be investigated not only through integration but also through the analysis of data diffraction. Data diffraction allows the 'emergence of disjuncture, lacunae, difference, and diversion as a means of troubling the research case as a bounded, isolated unit and revealing the ways in which processes of objectification, the making of the research object, take place' (Uprichard \& Dawney, 2019, p. 27).

The study of literacy through mixed methods following a causal logic produces convergent and divergent interpretations regarding the meaning and value of literacy. The integration of quantitative and qualitative data facilitates a clearer and more coherent representation of a complex social phenomenon as literacy. The integrated use of both approaches allows addressing that complexity of studying literacy practices through the lens of children, their teachers, and their families. Our study focused on literacy using mixed methods and we aimed to establish causal inferences by relying on the use of structural equations, on the one hand, and Mahoney's logic $(1999,2000)$, on the other hand. The use of mixed methods in our study went beyond the mere utilisation of both approaches and it affected the process, content, and contexts in which the study was carried out (Plano Clark \& Ivankova, 2016; Ivankova \& Plano Clark, 2018).

Overall, the employment of mixed methods helped to interpret the diffractions observed in literacy practices. The research questions (RQs) were as follows:

RQ1. What is the added value of the integration of quantitative and qualitative approaches in the understanding of literacy as a social practice of children, families, and teachers?

RQ2. What type of causal inferences are constructed between literacy as a social practice and the different interaction spaces? 


\section{Method}

This study was conducted following a sequential mixed methods design $(Q U A N \rightarrow$ qual). This quantitatively driven, sequential mixed methods design examined the opinions of pupils, their families, and their teachers regarding pupils' literacy practices. Three selfreport questionnaires were administered to participants, one for each participant depending on their group (i.e. children, families, teachers). The sequential qualitative component analysed pupils' everyday reading and writing practices and their social value. Researchers observed pupils within and outside the school and conducted interviews with pupils, families, and teachers. The point of interface of the two components was the causal inferences between children's literacy, on the one hand, and the family and school context on the other.

\section{Participants}

The data for the QUANT Component were from 20 public and state-funded nursery and primary schools in the province of Seville (Andalusia, Spain). The participating schools were stratified according to the model used in the Progress in International Reading Literacy Study 2016 (LaRoche, Joncas, \& Foy, 2017), which considers two main strata: school type and socioeconomic status (SES). The SES index of the schools was obtained from the Andalusian regional government. This index is a factorial score obtained on the basis of the parents' educational and occupational level and the number of books and material resources in the home (Gil Flores, 2013). The index is calculated by administering a questionnaire with the families, analogous to the one used by Organisation for Economic Co-operation and Development's international tests (e.g. PIRLS 2016). School selection was based on two criteria. First, schools had to accept the research requirements and sign an informed consent form as an educational institution. Second, each school had to have the participation of at least $80 \%$ of the families and their children in the selected grades/years of primary education (813 years of age).

Children's families or legal guardians signed an informed consent form that they had to hand in within a set period. In all cases, participation was voluntary and followed the rules of informed consent, which restricts the use of information to research purposes only and ensures anonymity and confidentiality. This study followed the internal regulations in the Social Sciences by the Research Ethics Committee at the University of Seville.

Participants in the QUANT Component were 1,540 children, 1,438 families, and 74 teachers. To associate each child with their corresponding family and teacher, the final sample comprised 791 children, their families, and their teachers. The sample did not include children whose families or teachers did not submit the self-report questionnaire. Thus, the answers of each child were matched with their family and their teacher.

The sample for the qual Component included three of the schools that participated in the QUANT Component. The selection criterion was SES; thus, three schools were chosen: those that best represented high, medium, and low SES, respectively. Two children $(n=6)$ were selected from each school using an extreme cases method (Patton, 2002; Flick, 2009). The criterion used for the selection of cases was the polarity of literacy practices within and outside each child's school. Each of the six cases was represented by a child, their family, and their teacher (see Table 1). 
Table 1. Participants in the qual Component

\begin{tabular}{|c|c|c|c|}
\hline $\begin{array}{l}\text { SES/ } \\
\text { School }\end{array}$ & & Case description & \\
\hline 它 & $\begin{array}{l}= \\
\overline{8} \\
\frac{0}{0} \\
\tilde{n}\end{array}$ & $\begin{array}{l}\text { Name: Martina } \\
\text { Age: } 12 \text { years old } \\
\text { Gender: female } \\
\text { Nationality: Spanish } \\
\text { Dwelling: owned dwelling } \\
\text { Members of the family unit: } 4 \text { (father } \\
\text { [aged 47], mother [aged 45], brother } \\
\text { [aged 28]) } \\
\text { Father's educational level: Secondary } \\
\text { school } \\
\text { Mother's educational level: Secondary } \\
\text { school } \\
\text { Father's occupation: self-employed } \\
\text { Mother's occupation: housewife } \\
\text { Sibling's occupation: office clerk }\end{array}$ & $\begin{array}{l}\text { Name: Cloe } \\
\text { Age: } 11 \text { years old } \\
\text { Gender: female } \\
\text { Nationality: Spanish } \\
\text { Dwelling: owned dwelling } \\
\text { Members of the family unit: } 4 \text { (father } \\
\text { [aged 43], mother [aged 42], sister [aged } \\
\text { 16]) } \\
\text { Father's educational level: Secondary } \\
\text { school } \\
\text { Mother's educational level: Secondary } \\
\text { school } \\
\text { Father's occupation: self-employed } \\
\text { Mother's occupation: housewife }\end{array}$ \\
\hline$\frac{\Xi}{\Xi}$ & $\begin{array}{l}\text { N } \\
\frac{0}{8} \\
\frac{1}{0} \\
\mathscr{n}\end{array}$ & $\begin{array}{l}\text { Name: Roberto } \\
\text { Age: } 12 \text { years old } \\
\text { Gender: male } \\
\text { Nationality: Spanish } \\
\text { Dwelling: owned dwelling } \\
\text { Members of the family unit: } 4 \text { (father } \\
\text { [aged 38], mother [aged 37], sister } \\
\text { [aged 2]) } \\
\text { Father's educational level: Secondary } \\
\text { studies } \\
\text { Mother's educational level: Secondary } \\
\text { studies } \\
\text { Father's occupation: self-employed } \\
\text { Mother's occupation: unemployed }\end{array}$ & $\begin{array}{l}\text { Name: Amaya } \\
\text { Age: } 12 \text { years old } \\
\text { Gender: female } \\
\text { Nationality: Spanish } \\
\text { Dwelling: social rental housing } \\
\text { Members of the family unit: } 4 \text { (father } \\
\text { [aged 46], mother [aged 43], sister [aged } \\
7 \text { ]) } \\
\text { Father's educational level: Primary } \\
\text { studies } \\
\text { Mother's educational level: Secondary } \\
\text { studies } \\
\text { Father's occupation: obrero } \\
\text { Mother's occupation: unemployed }\end{array}$ \\
\hline 3 & $\begin{array}{l}n \\
\frac{0}{8} \\
\frac{0}{0} \\
\tilde{n}\end{array}$ & $\begin{array}{l}\text { Name: Damián } \\
\text { Age: } 12 \text { years old } \\
\text { Gender: male } \\
\text { Nationality: Spanish } \\
\text { Dwelling: owned dwelling } \\
\text { Members of the family unit: } 4 \text { (father } \\
\text { [aged 43], mother [aged 42], sister } \\
\text { [aged 16]) } \\
\text { Father's educational level: Primary } \\
\text { studies } \\
\text { Mother's educational level: Secondary } \\
\text { school } \\
\text { Father's occupation: labourer } \\
\text { Mother's occupation: unemployed }\end{array}$ & $\begin{array}{l}\text { Name: Hiba } \\
\text { Age: } 12 \text { years old } \\
\text { Gender: female } \\
\text { Nationality: Moroccan } \\
\text { Dwelling: Free-rental subsidised } \\
\text { housing } \\
\text { Members of the family unit: } 6 \text { (father } \\
\text { [aged 58], mother [aged 60], elder } \\
\text { brother [aged 25], middle brother } 1 \\
\text { [aged 17], middle brother } 2 \text { [aged 14] } \\
\text { Father's educational level: No formal } \\
\text { education or training } \\
\text { Mother's educational level: No formal } \\
\text { education or training } \\
\text { Father's occupation: street vendor } \\
\text { Mother's occupation: unemployed }\end{array}$ \\
\hline
\end{tabular}

\section{Data collection procedure}

The self-report questionnaires used in the QUANT Component had 29 items that were common to the three sets of participants (pupils, families, and teachers), which measured literacy practices developed in the space of personal literacy, cultural consumption, library, and school. The dimensions of literacy events and domains that were considered are described in Table 2. 
Table 2. Dimensions of literacy events and domains in primary education

\begin{tabular}{llll}
\hline Dimensions & Description & Domains & \\
\hline Personal Literacy & $\begin{array}{l}\text { Literacy events developed in different } \\
\text { spaces and acquired as non-formal and } \\
\text { informal learning. }\end{array}$ & $\begin{array}{l}\text { Affinity groups } \\
\text { neighbourhood, in } \\
\text { Instagram, etc. }\end{array}$ & $\begin{array}{c}\text { in } \\
\text { families, on }\end{array}$ \\
\hline Cultural Consumption & $\begin{array}{l}\text { Literacy events developed in different } \\
\text { spaces and related to the purchase and sale } \\
\text { of literacy products. }\end{array}$ & $\begin{array}{l}\text { Affinity groups } \\
\text { neighbourhood, in in families, on } \\
\text { Instagram, etc. }\end{array}$ \\
\hline Library Culture & $\begin{array}{l}\text { Literacy events developed in different } \\
\text { spaces and related to the use of public and } \\
\text { private libraries. }\end{array}$ & $\begin{array}{l}\text { Affinity groups in families and at } \\
\text { school, etc. }\end{array}$ \\
\hline Culture of Instruction & $\begin{array}{l}\text { Literacy events developed in different } \\
\text { spaces and acquired as formal learning in } \\
\text { an educational institution. }\end{array}$ & \\
\hline Source: Adapted from Guzmán-Simón, Moreno-Morilla, \& García-Jiménez (2018) \& Moreno-Morilla, Guzmán- \\
Simón, \& García-Jiménez (2017).
\end{tabular}

A description of the three self-report shows the dimensions, the questions, and the 29 questionnaires structure is shown in Table 3. It items that were used.

Table 3. Structure of the self-report questionnaire

\begin{tabular}{|c|c|c|}
\hline Dimension & Questions & Items \\
\hline \multirow{8}{*}{$\begin{array}{l}\text { Personal } \\
\text { Literacy }\end{array}$} & Where do you typically read? & 1. At home \\
\hline & & 2. At school \\
\hline & & 3. In the library \\
\hline & In what format or media do you typically write? & 4. On paper \\
\hline & & 5. On a computer \\
\hline & & 6. On a mobile phone \\
\hline & & 7. On a tablet \\
\hline & $\begin{array}{l}\text { When you write on digital media, where do you } \\
\text { tend to do so? }\end{array}$ & $\begin{array}{l}\text { 8. On social networks } \\
\text { 9. On blogs }\end{array}$ \\
\hline \multirow{5}{*}{$\begin{array}{l}\text { Cultural } \\
\text { Consumption }\end{array}$} & Where do you typically buy books? & 10. In a bookshop \\
\hline & & 11. On the Internet \\
\hline & What events have you attended? & 12. Bookfair \\
\hline & & 13. Storytelling sessions \\
\hline & & 14. Writing workshop \\
\hline \multirow{4}{*}{$\begin{array}{l}\text { Library } \\
\text { Culture }\end{array}$} & For what purpose does your child typically use & 15. As a reading room \\
\hline & libraries? & 16. As a group workspace \\
\hline & & 17. As a loan service \\
\hline & & 18. As a place to access the Internet \\
\hline \multirow{11}{*}{$\begin{array}{l}\text { Culture } \\
\text { Instruction }\end{array}$} & What type of texts are most often read at & 19. Textbooks \\
\hline & school? & 20. Journal articles \\
\hline & & 21. Reading books \\
\hline & & 22. Class notes \\
\hline & & 23. Photocopies \\
\hline & How are the recommended readings used in & 24. Through debates \\
\hline & class? & 25. Through pupils' reflection \\
\hline & & 26. Through reading analysis by teachers \\
\hline & After reading some notes, books, journal & 27. Summaries \\
\hline & articles, or other recommended texts, what & 28. Outlines or mind maps \\
\hline & activities are carried out? & 29. Reflections \\
\hline
\end{tabular}


Each of the items was evaluated using a Likert scale ranging from 0 (Never) to 5 (Always). Self-report questionnaires underwent a validation process using the non-metric multidimensional scaling (PROXSCAL) (Moreno-Morilla, García-Jiménez, \& GuzmánSimón, 2018). To that end, a proximity matrix was created so that the transformed proximities would maintain the same order as the originals. The four values that measured imbalance in the data or stress statistics received scores close to zero, and the adjustment measures approached one (Dispersion Accounted For [DAF] and Tucker's Congruence Coefficient [TCC]). The reliability, measured using Cronbach's alpha, was 0.915 for the pupils', 0.799 for the families', and 0.900 for the teachers' self-report questionnaires.

Fieldwork in the qual Component had a duration of 18 months, which included two academic years. In this period, researchers conducted in-depth interviews with children and family members about their children's everyday reading and writing practices at home
(Rowsell \& Pahl, 2007). Researchers also interviewed teachers about their school literacy practices. The interview questions were based on the dimensions of the self-report questionnaire (personal literacy, cultural consumption, library culture, and culture of instruction) described in Table 2.

In addition to the interviews, systematic observation of the literacy events in each of the spaces was undertaken. In the home space, researchers undertook three-fortnight observations in which children constructed mappings about their literacy practices in the different spaces. The children completed reading and writing passports and wrote a personal biography and a narration of their literacy practices. In the school space, researchers collected the children's productions, constructed different mappings (diagrams made from pictures that represented meanings perceived by children regarding a place or domain) and maintained informal conversations with the children throughout the whole process (see Table 4).

Table 4. Records of QUANT $\rightarrow$ qual components

\begin{tabular}{|c|c|c|c|}
\hline \multicolumn{3}{|c|}{ Data collection } & $\begin{array}{l}\text { Number/ } \\
\text { time }\end{array}$ \\
\hline \multirow{5}{*}{ 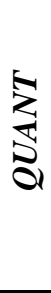 } & \multicolumn{2}{|c|}{ Pupils' self-report questionnaires } & 791 \\
\hline & \multicolumn{2}{|c|}{ Families' self-report questionnaires } & 791 \\
\hline & \multicolumn{2}{|c|}{ Teachers' self-report questionnaires } & 74 \\
\hline & \multicolumn{2}{|c|}{$\begin{array}{l}\text { Reports on the Economic, Social and Cultural } \\
\text { Status of the schools }\end{array}$} & 3 \\
\hline & \multicolumn{2}{|c|}{$\begin{array}{l}\text { Reports on the results of General Diagnosis } \\
\text { Assessments }\end{array}$} & 6 \\
\hline \multirow{14}{*}{$\mathbb{\Xi}$} & \multirow{7}{*}{ Pupils' productions } & My favourite domain & 6 \\
\hline & & Biography & 6 \\
\hline & & $\begin{array}{l}\text { Reading and writing } \\
\text { passport I }\end{array}$ & 6 \\
\hline & & $\begin{array}{l}\text { Reading and writing } \\
\text { passport II }\end{array}$ & 6 \\
\hline & & Home mapping & 6 \\
\hline & & School mapping & 6 \\
\hline & & Internet mapping & 6 \\
\hline & \multirow{3}{*}{$\begin{array}{l}\text { Interview } \\
\text { recordings }\end{array}$} & Pupils & $18 \mathrm{~h} \mathrm{43^{ \prime }}$ \\
\hline & & Families & 9h 24' \\
\hline & & Teachers & $6 h 38^{\prime}$ \\
\hline & \multicolumn{2}{|c|}{ Conversation video recordings } & 21h $15^{\prime}$ \\
\hline & \multicolumn{2}{|c|}{ Discussion group video recordings } & 6 \\
\hline & \multicolumn{2}{|c|}{$\begin{array}{l}\text { Screenshots of children's and families' events } \\
\text { and practices }\end{array}$} & 631 \\
\hline & \multicolumn{2}{|l|}{ Photographs } & 470 \\
\hline
\end{tabular}




\section{Data analysis}

The self-report questionnaires were analysed through a correlational analysis in the QUANT Component. This kind of analysis allows us to establish the possible relationship between children's literacy in primary education and that of their families and teachers. This analysis is the basis for the establishment of causal inferences between contextual and school variables (school ownership and SES) and the participants' opinions as collected in the selfreport questionnaires. A Structural Equation Model for Multiple-Group (SEM) was developed to establish causal inferences. The estimation method used was Likelihood.

The observations, interviews, discussion groups, and mappings were analysed using a Comparative Qualitative Analysis (CQA) of the practices of the six children in the qual Component. This analysis was undertaken from the framework of social semiotics (van Leeuwen, 2005), which addresses the understanding of multimodal communication from the perspective of qualitative research (Dicks, Soyinka, \& Coffey, 2006). The establishment of causal relationships took as its starting point the results obtained from the multimodal discourse analysis (Bezemer \& Kress, 2016; Kress, 2010).

The integration of the analysis of QUANT $\rightarrow$ qual data was guided by the RQs and it crosschecked the inferences found or excluded in the QUANT and qual analyses. Thus, each causal inference was checked using quantitative and qualitative evidence as a reference (Harding \& Seefeldt, 2014).

\section{Results}

\section{Literacy practices in different spaces}

The study of the literacy practices of pupils, their families, and their teachers helped us to identify the social value that these groups give to literacy. Literacy events and practices were located in spaces that are constructed through the interaction of the participants in places such as the school, the home, or the neighbourhood.

Participants' ratings indicated that the teachers and pupils identified more with the literacy practices developed in the school ( $\overline{\mathrm{X}} \geq 3.05,5$ max.). This space involved those literacy events that basically incorporated written texts and school readings.

The literacy developed in the school coexisted with the literacy developed in pupils', their families', and their teachers' personal spaces. However, families, teachers, and pupils considered that personal literacy was less important than school literacy. The average scores that these groups gave to their personal spaces were between 2.17 and 2.75. At the same time, the school was rated with average scores between 3.05 and 3.39.

The literacy events were held in the spaces of cultural consumption and libraries reached even lower rates from the children and their families. The average scores in the self-report questionnaires ranged from 2.06 to 2.24 in relation to production and consumption spaces, and from 1.61 to 2.22 in relation to the library.

The qualitative data confirmed the findings obtained from the quantitative analysis and showed the prevalence of the school space over the rest of the literacy spaces. Nevertheless, the integration of the qualitative data indicates that the literacy practices developed at the school were influenced by the teachers', families' and children's personal practices outside the school. Teachers' personal practices influenced the use of printed and handwritten materials within and outside the school. These results confirmed those obtained from the QUANT Component, as shown by Roberto and Amaya's teacher:

I always follow the textbook in class; we never use computers or those kinds of things. That is for younger teachers. In any case, I do not think it is good for children. It is not easy to find reliable information on the Internet. Besides, children's handwriting is getting worse and worse [...]; they make more mistakes. Writing is losing its value, all because of so many digital media (Roberto and Amaya's teacher, date 18-06-18).

The social value that the teachers transmit into the school space was closely related to their personal practices. This revealed a clear ideological predominance of the cultural value 
of the printed word, as described in the following observation:

Tere (Roberto and Amaya's teacher) uses a negative discourse, which is generalised among school teachers, when talking about children's use of digital media. Teachers object to its incorporation into the classroom. Furthermore, schoolteachers demonstrate low digital competence in the development of their teaching profession [field note, 10-04-18].

It was found that children's literacy practices were developed both at school and at home. The children did their homework in the home and brought school literacy practices into this space. In addition to school practices, the children developed other personal literacy practices as well. The representation of these personal practices (e.g. reading and writing on their mobile phone, on Instagram; etc.) depended on the social value given to this type of practices by families. The analysis of quantitative data demonstrates high variability among the families regarding higher or lower use of digital media. An example of this relationship was found in the practices developed by two children, Martina and Cloe. Martina's family encouraged the development of practices that foster the use of print materials ('There are always books at home, we are not bookworms, but because of a lack of time, because of our jobs, I always try to keep on studying' [interview with Martina's mother, 31-05-17]). Consequently, Martina gave higher social value to the practices based on the use of printed materials as opposed to digital practices. ('The Internet can also provide much value, but reading books is more traditional, and that is why the children in our school prefer reading books' [interview with Martina, 31-05-17]). The observations made in Martina's home demonstrate her positive assessment of the print literacy demanded by the school. For Martina, her personal literacy practices were subordinate to the school practices, as reflected in the following field note:

Martina arrives from school, has lunch with her family and, right after finishing, she goes to her room, where she spends most of the afternoon. First, she does her homework and then she goes through her diary to order and distribute the study days for each exam. Anything that is not studying or doing homework is a waste of time for her (field note, 28-05-18).

The personal literacy practices of Martina's family were in contrast with those of other participants. Cloe's family fostered the development of digital practices through the mobile phone. This motivated Cloe's insufficient appreciation for the literacy developed at school, which is based on printed resources. The observation of Cloe's literacy practices in her home showed the importance of her personal practices through the use of digital media:

Cloe does not usually do her homework, and if she does, it is done very quickly and carelessly. The three (mother and daughters) spend the whole time using their mobile phones, mainly texting and sharing images and videos on WhatsApp. Cloe's mother has a very active role on Facebook, whereas Cloe and her sister (aged 14) mainly opt for the use of Instagram (field note, 22-02-18).

The practices developed by children within and outside the school reinforced the social value given to literacy in each of the schools. The observations undertaken in the schools reflected a wide heterogeneity in the use of digital media. Nonetheless, digital practices were scarce when compared to print school practices in all the schools that were considered in the analysis. Figure 1 shows the mappings carried out by the children, which characterised their view of literacy practices developed at school. The mapping of School 1 presents a literacy process that did not incorporate any digital media. Similarly, it highlights the importance of school grades for children (see graded exams in the tables) and compliance with the rules (see, for example, classroom rules, mobile phones prohibited poster, etc.). The mapping that represents School 2 displays a classroom equipped with digital media for the exclusive use of the teacher. The observations 
made in this classroom and the comments made by the pupils demonstrate that the teacher did not propose tasks that involved the use of the digital board by the children. The mapping of School 3 represents a classroom with digital media, for both the teacher and the pupils. On the one hand, the digital board was used only by the teacher to show videos, blogs, etc. On the other hand, pupils used their laptops one hour a week (half an hour on Thursdays and half an hour on Fridays to listen to music, write on social media, watch videos on YouTube, etc. [interview with Hiba, 30-03-17]). Hiba's case stresses the insufficient use of ICT at school:

Everything is digital at home, and you get to school and that is the end of it. I like writing on paper, I am not saying I do not, but I also like writing on the computer. The teacher has a computer that he uses to print worksheets and exams, just for that. We have the laptops on Thursdays and Fridays, only for a little while [interview with Hiba, 30-03-17].

Figure1. Mapping of literacy practices at school

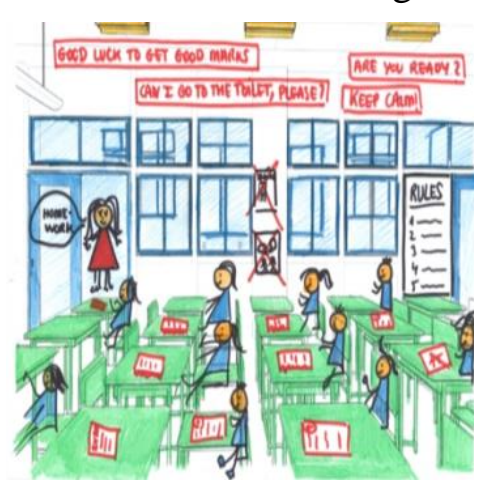

School 1: Martina's mapping

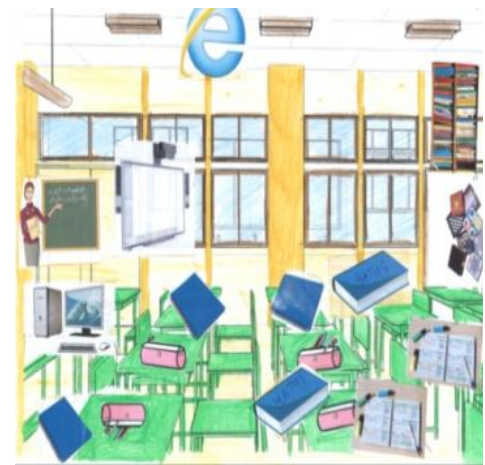

School 2: Roberto's mapping

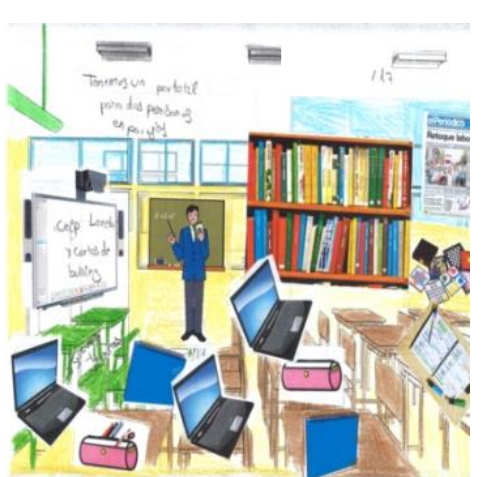

School 3: Hiba's mapping

N.B. The children created the figures using images and stickers that identified digital and print media in the classroom, as well as the literacy events developed.

The contrast in the information provided by the different sources in this research highlights wide variability in literacy outside the school. Children develop a higher or a lower diversity of personal practices depending on the social value that children give to school literacy. Figure 2 presents examples of the mappings carried out by children to reflect their practices outside the school. Mapping 1 represents Martina's room as an extension of the classroom. The room was full of books, notebooks, diaries, and other school materials. In this manner, the only represented digital medium was a desktop computer on which Martina drew a cross and wrote 'not much'. All the actions represented in the drawing related to homework and the reading of books that Martina borrowed from the school library (for which she received an extra grade). Mapping 2 depicts a type of literacy that was clearly printed and individual (the reading of a newspaper) carried out in a park. Lastly, Mapping 3 involves various literacy practices, also carried out in a park. In this mapping, Hiba made use of her mobile phone, watched videos on her tablet, bought children's magazines at the kiosk, sent a letter to her family in Morocco, and did graffiti with her friends. 
Figure 2. Mappings of literacy practices outside the school

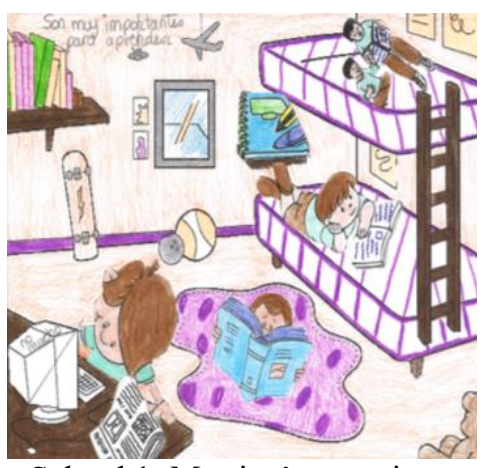

School 1: Martina’s mapping

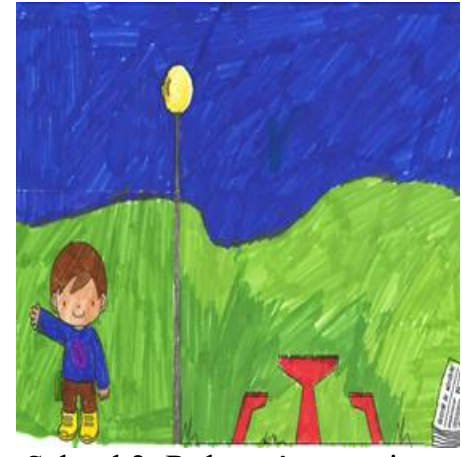

School 2: Roberto's mapping

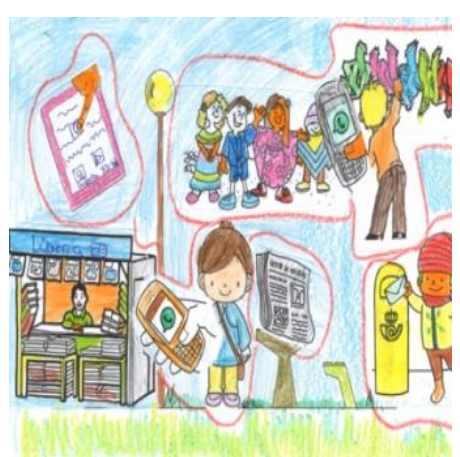

School 3: Hiba's mapping
In conclusion, the previously described results show the heterogeneity of literacy practices within and outside the school. The integration of quantitative and qualitative data signals the need to study the influence of literacy practices within and outside the school on children's personal practices.

\section{Teachers' and families' literacy practices as inducement for pupils' practices}

The analysis of the pupils' literacy practices, conducted through self-report questionnaires, mappings, or interviews, demonstrates a connection with the practices of the teachers and the families. First, the study of these possible relationships was addressed by calculating the Pearson correlation coefficient among the self-report questionnaire items. Table 5 shows the correlations between the literacy events of the pupils, their families, and their teachers. This table also reflects the connections between these literacy events and variables such as school ownership (public or private) and the SES. The data show that there were statistically significant correlations among the different spaces for each of the groups. The highest correlations corresponded with the relationship between the personal literacy space and the cultural consumption space $\quad\left(\mathrm{rXY}=0.403\right.$, children; $\mathrm{r}_{\mathrm{XY}}=0.424$, teachers; rXY0.432, families). The relationships between the cultural consumption spaces and the library were above 0.40 among the children $\left(\mathrm{r}_{\mathrm{XY}}=0.471\right)$.

Table 5. Correlation matrix according to the variables considered in the pupils', families', and teachers' self-report questionnaires

\begin{tabular}{|c|c|c|c|c|c|c|c|c|c|c|c|}
\hline & SES & S_PL & S_PC & S_L & S_S & F_PL & F_PC & F_L & T_PL & T_PC & T_S \\
\hline SES $^{\mathrm{a}}$ & 1 & & & & & & & & & & \\
\hline $\mathrm{CPL}^{\mathrm{b}}$ & $-0.073^{*}$ & 1 & & & & & & & & & \\
\hline $\mathrm{CCC}^{\mathrm{c}}$ & $0.130^{* *}$ & $0.403^{* *}$ & 1 & & & & & & & & \\
\hline$C L^{d}$ & -0.019 & $0.443^{* *}$ & $0.471^{* *}$ & 1 & & & & & & & \\
\hline $\mathrm{SCL}^{\mathrm{e}}$ & -0.054 & $0.079^{*}$ & $0.113^{* *}$ & $0.130^{* *}$ & 1 & & & & & & \\
\hline FPL $^{f}$ & -0.055 & $0.117^{* * *}$ & $0.086^{*}$ & $0.101^{* *}$ & 0.061 & 1 & & & & & \\
\hline $\mathrm{FCC}^{\mathrm{g}}$ & $0.090^{*}$ & 0.027 & $0.119^{* * *}$ & 0.018 & $0.082^{*}$ & $0.432^{* *}$ & 1 & & & & \\
\hline $\mathrm{FL}^{\mathrm{h}}$ & $-0.083^{*}$ & $0.080^{*}$ & $0.077^{*}$ & $0.166^{* *}$ & $0.110^{* *}$ & $0.388^{* *}$ & $0.378^{* * *}$ & 1 & & & \\
\hline $\mathrm{TPL}^{\mathrm{i}}$ & -0.012 & $0.175^{* *}$ & $0.179^{* *}$ & $0.093^{* *}$ & 0.069 & 0.050 & 0.033 & $0.073^{*}$ & 1 & & \\
\hline $\mathrm{TCC}^{\mathrm{j}}$ & $0.157^{* *}$ & $0.107^{* *}$ & $0.195^{* *}$ & $0.148^{* *}$ & $0.076^{*}$ & $0.072^{*}$ & 0.021 & $0.168^{* *}$ & $0.424^{* *}$ & 1 & \\
\hline $\mathrm{TSL}^{\mathrm{k}}$ & 0.068 & 0.051 & $0.139^{* *}$ & $0.094^{* *}$ & $0.126^{* *}$ & $0.075^{*}$ & 0.057 & $0.086^{*}$ & $0.308^{* * *}$ & $0.402^{* *}$ & 1 \\
\hline $\mathrm{N}$ & 791 & 791 & 791 & 790 & 787 & 791 & 791 & 791 & 791 & 791 & 791 \\
\hline $\bar{x}$ & -0.37 & 2.75 & 2.24 & 2.33 & 3.05 & 2.17 & 2.06 & 1.61 & 2.65 & 2.52 & 3.39 \\
\hline Sx & 0.52 & 0.83 & 0.98 & 1.34 & 0.98 & 0.70 & 0.79 & 1.22 & 0.76 & 0.85 & 0.75 \\
\hline & Note: ${ }^{*} \mathrm{p}$ & \multicolumn{4}{|c|}{$\begin{array}{l}\text { a Socioeconomic Status } \\
\text { b Children's Personal Literacy } \\
\text { c Children's Cultural Consumption } \\
{ }^{\mathrm{d}} \text { Children's Library } \\
{ }^{\mathrm{e}} \text { Children's School Literacy }\end{array}$} & \multicolumn{6}{|c|}{$\begin{array}{l}\text { f Families' Personal Literacy } \\
\text { g Families' Cultural Consumption } \\
\text { h Families' Library } \\
\text { i Teachers' Personal Literacy } \\
\text { j Teachers' Cultural Consumption } \\
\text { k Teachers' School Literacy }\end{array}$} \\
\hline
\end{tabular}


The estimations made by the explained variance model in the observed variables indicate that the TPL (Square Multiple Correlation $=0.924$, henceforth SMC) and FPL $($ SMC $=0.738)$ variables had a better prediction. In this case, the items that measured the TPL explain the $92.4 \%$ of the variance in this dimension. Similarly, $73.8 \%$ of the variance in the families' Personal literacy was accounted for by the items that constituted it.
Children's literacy practices had a value of $\mathrm{SMC}=0.355$, which indicates that $35.5 \%$ of the variance observed in this factor was accounted for by the predictors. Teachers' literacy practices (TPL) constituted the best predictor of children's literacy practices (CLP) with a Standardised Regression Weight (SRW) of 0.507 , above families' literacy practices (FLP), with a SRW of 0.312 (see Figure 3)

Table 7. Standardised Regression Weights

\begin{tabular}{lclc}
\hline Observed variables & & Latent variables & Estimate \\
\hline CHILDREN'S_PRACTICES & $<---$ & TEACHERS'_PRACTICES & 0.507 \\
CHILDREN'S_PRACTICES & $<---$ & FAMILIES'_PRACTICES & 0.312 \\
TPL & $<---$ & TEACHERS'_PRACTICES & 0.961 \\
TS & $<---$ & TEACHERS'_PRACTICES & 0.329 \\
CL & $<---$ & CHILDREN'S_PRACTICES & 0.249 \\
CPL & $<---$ & CHILDREN'S_PRACTICES & 0.402 \\
FPL & $<---$ & FAMILIES'_PRACTICES & 0.859 \\
FCC & $<---$ & FAMILIES'_PRACTICES & 0.508 \\
SS & $<---$ & CHILDREN'S_PRACTICES & 0.178 \\
FCC & $<---$ & SES & 0.129 \\
\hline
\end{tabular}

Standardised Regression Weights for latent variables onto an observed variable show that observed variables best explained by correspondent latent variables were those related to personal literacy practices (TPL=0.961, FPL=0.859, and CPL=0.402).
Teachers' and students' Culture of Instruction was moderately explained by literacy practices (TCI $=0.329$, SCI $=0,178$ ). The $50.8 \%$ of the variance in FCC was explained by the families' literacy practices. The FCC was poorly explained by SES.

Figure 3. Children's literacy structural equation model

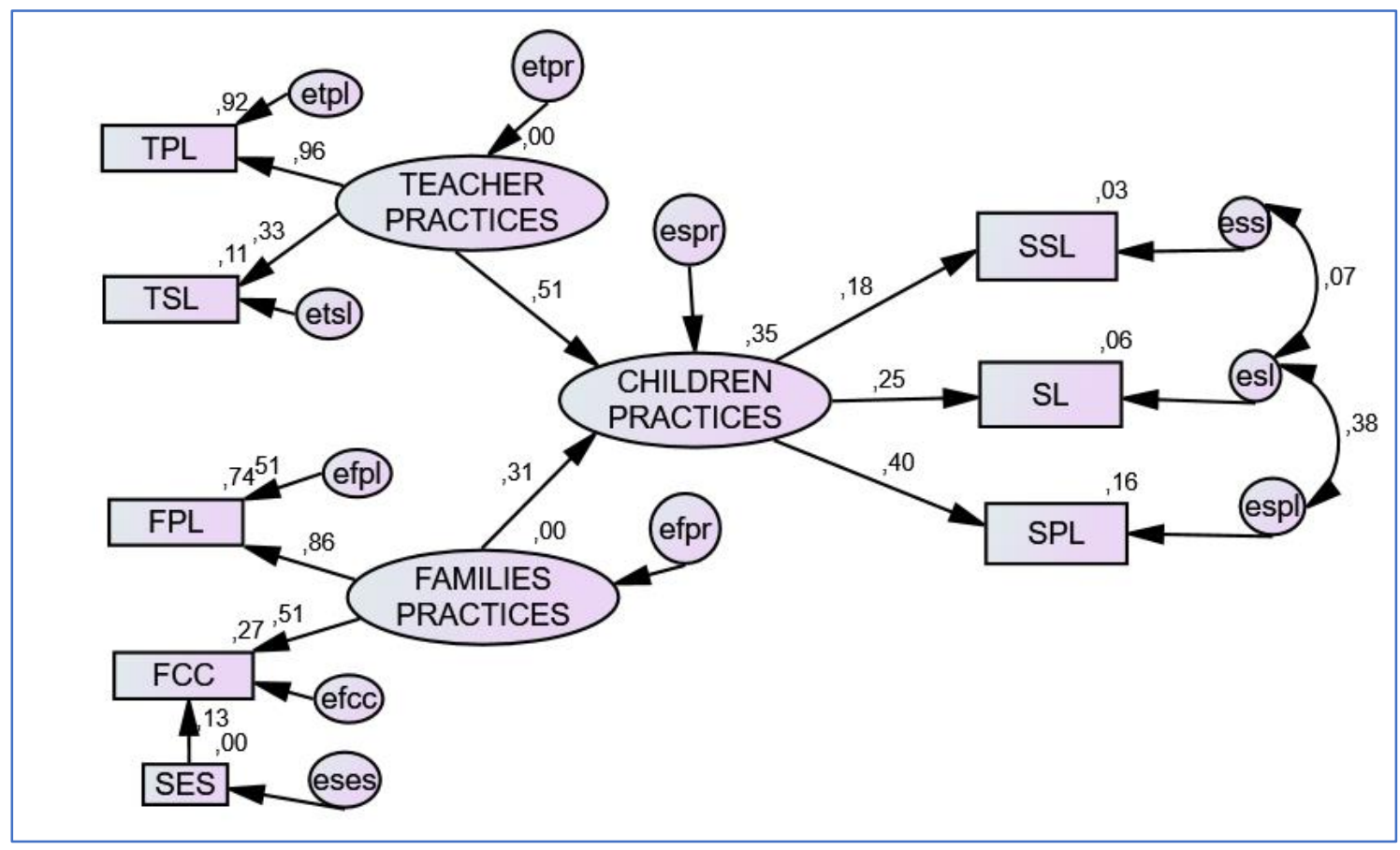




\section{The integration of $Q U A N T \rightarrow$ qual causal inferences}

The literacy practices represented in the SEM and in the causal-inferential analysis of the qualitative analysis highlight some common findings. Students' practices were predicted by the teachers' and the families' practices, both in the SEM and in the CQA. First, the teachers' personal literacy practices $\left(\mathrm{R}_{\mathrm{ts}}=0.507\right)$ accounted for the type of instructional practices that the children received in the classroom (Table 5). These practices entailed eminently print literacy as Martina's teacher (School 1) pointed out in the following quotation:

I always work with reading and writing on paper; I seldom use digital media, to be honest. I feel more comfortable with paper-based teaching. [...] Sometimes, I do not even want to get on the Internet, the things that are written there are terrible. On the Internet, there are a great deal of typos, orthographic errors, stylistic errors, etc. This is why I personally and professionally do not think that digital media are benefiting literacy processes, and I always insist on it with the families (interview with Martina's teacher, 28/06/17).

Martina's literacy practices were framed within the social value that her teacher gave to literacy. This social value was positive in relation to print literacy; and it was negative when literacy developed through the interaction with digital media:

I always read and write on paper. I like going through everything that we have seen at school, and then, doing all my homework. That is the first thing I do. Moreover, I keep improving my handwriting by writing on paper. My handwriting is getting better and better; but this is not possible on the computer. [...] Teachers tell us at school: 'Read preferably books, please'. Besides, we attend talks where we are told about the negative effects of the media and social networks. We are very well informed. Our teachers insist a lot on this (interview with Martina, 14/06/17).

Second, the literacy practices of the families predict, to a certain extent, the practices developed by children according to the SEM $\left(\mathrm{R}_{\mathrm{fs}}=0.312\right)$ and, to a greater extent, according to the CQA. Students' personal literacy practices, especially those related to digital literacy, demonstrate a clear relationship of dependence with the practices developed in the home (see Table 5). The qualitative data revealed this relationship in a clearer way. For instance, Cloe was a girl who went to School \#1 and her teacher was the same as Martina's. Cloe's family gave positive social value to the use of literacy digital media. The results obtained show that Cloe's mother, without questioning the role of the school, was a firm defender of literacy based on digital media:

I am used to writing mainly on WhatsApp to chat with my friends; I usually read news and share quotes on Facebook... On Instagram, more of the same thing, etc. At home, there are a few books, not many, because we are more into mobile phones, tablets, and all that stuff [...]. I think the Internet offers a great opportunity to look for information, it can also help improve spelling. They can find further and more updated information on the Internet. I do not think writing on social networks is harmful to them, although I always check everything she does when she is on Instagram" (interview with Cloe's mother, 18/09/17).

Cloe's literacy practices reflect the positive value given to the use of digital media. Like her mother, Cloe used mobile devices in her personal literacy, and defended the view of incorporating these media into the school:

When I wake up in the morning, I take my phone to check if I have received something, be it on WhatsApp or 
Instagram. We never use computers at school; we only read and write on paper. I would like to use computers or tablets in the classroom, although I also like writing on paper (interview with Cloe, 15/10/17).

Children's literacy practices, which reflect the varying social value that the families gave to literacy, developed independently from the SES. The type of cultural consumption done by families and children was related to the personal literacy practices developed in the home. Table 8 shows that the SES did not determine the type of consumption. All the homes had access to the Internet and paid TV channels; the number of books in the home varied within the same SES (e.g. see Martina and Cloe) and it was not related to SES (e.g. see Martina and Damián). The number of laptops, tablets, game consoles, televisions, etc., was similar across the different SES levels.

Table 8. Material and digital resources in the home belonging to cultural consumption

\begin{tabular}{|c|c|c|c|c|c|c|c|c|c|}
\hline & Cases & & Laptop & Tablet & Mobile & TV & Book & Console & $\begin{array}{l}\text { Video- } \\
\text { game }\end{array}$ \\
\hline High & $\operatorname{Martina}\left(3_{\mathrm{NPH}}\right)$ & \multirow{6}{*}{$\begin{array}{l}\text { Access to } \\
\text { the Internet } \\
\text { and } \\
\text { payment } \\
\text { for TV } \\
\text { channels }\end{array}$} & 1 & 1 & 3 & 3 & 25 & 0 & 0 \\
\hline SES & Cloe $\left(3_{\mathrm{NPH}}\right)$ & & 1 & 0 & 3 & 3 & 9 & 1 & 4 \\
\hline Medium & Roberto $\left(4_{\mathrm{NPH}}\right)$ & & 1 & 1 & 2 & 2 & 60 & 1 & 6 \\
\hline SES & Amaya $\left(4_{\mathrm{NPH}}\right)$ & & 1 & 0 & 3 & 3 & 6 & 1 & 6 \\
\hline Low & Damián $\left(4_{\mathrm{NPH}}\right)$ & & 1 & 1 & 3 & 2 & 30 & 1 & 8 \\
\hline SES & Hiba $\left(6_{\mathrm{NPH}}\right)$ & & 1 & 0 & 6 & 2 & 6 & 1 & 11 \\
\hline
\end{tabular}

Note: $\mathrm{NPH}=$ Number of people in the home

The analysis of the quantitative data showed no differences regarding the number of digital and non-digital resources that the families had. Nevertheless, the analysis of qualitative data showed that the families and the students differed regarding the social value they gave to the different material and digital resources as well as their use. The digital literacy practices developed by the children were fundamentally related to the social value that their families gave to these practices.

\section{Discussion and conclusions}

The interpretation of a complex phenomenon such as literacy in which different agents intervene within and outside the school (Gee, 2015) acquires a new perspective in the integration of quantitative and qualitative approaches. The integration carried out in this study allowed us to understand the existing relationships among the variables that intervene in literacy and to establish causal inferences based on quantitative and qualitative data. The first aim of this study was to integrate students', families', and teachers' perspectives on literacy. The main challenge we faced in achieving this aim was to find out which data obtained through different methods could be interpreted together in a significant way.

The design of our study implemented integration by taking into account several criteria (Fielding, 2012; Nastasi, Hitchcock, \& Brown, 2010). The first criterion taken into account was the theoretical perspective of Literacy Studies. The QUANT $\rightarrow$ qual design used takes this theoretical perspective as a reference, in such a way that both the construction of the self-report questionnaires (QUANT Component) and the different procedures used in the qual Component were based on ethnographic research as proposed by Bloome (2012), Heath and Street (2008), and Tusting and Barton (2003). The second criterion was sampling integration. The cases selected for the qual Component were chosen from the sample of the QUANT Component. The third criterion was the priority of the qual Component over the QUANT Component in the interpretation of data. Literacy studies that address literacy from a sociocultural approach preferably use a qualitative methodology (e.g. Burnett \& Merchant, 2018; Escoot \& Pahl, 2017; Gillen \& Kucirkova, 2018; Hackett, 2017). In our study, the data obtained in the qual Component provide a thick description of 
the literacy practices. The analytical density provided by the CQA, through this type of description, allowed us to refine the interpretation of causal inferences obtained in the SEM.

The second aim of our study was to establish causal inferences between various types of literacy as a social practice of children in their personal and school spaces. This aim was achieved through the integration of quantitative and qualitative data.

\section{$Q U A N \rightarrow$ qual Integration}

The SEMs have become 'a core method for assessing hypothesised causal relationships in the social sciences' (Barringer, Eliason, \& Leahey, 2013, p.15). One of their main advantages is that they allow the construction of models in which several paths that lead to a result or effect are identified. The SEMs break down the hypothesised causal factors into their direct or indirect components, through the analysis of reciprocal effects observed in the data. In our study of literacy practices, the use of the SEMs facilitated the comprehension of causal chains between latent variables (CHILDREN'S PRACTICES) and observed variables (CCC, CL, CPL). The main causal inference determines that TEACHERS' PRACTICES (TPL and TSL) explain their students' literacy practices (CPL and SCL).

In our study, the CQA establishes causal inferences that partially confirm the SEM's results. The teachers' literacy practices determine children's practices. Thus, literacy as a social practice assumes that the school space has a relevant role in children's development, at least in the domain of print literacy (Moreno-Morilla, Guzmán-Simón, \& García-Jiménez, 2017). Nevertheless, this influence of teachers on children's literacy must be interpreted on the basis of the personal literacy practices developed in the home (Moreno-Morilla, Guzmán-Simón, \& GarcíaJiménez, 2019).

The use of the SEMs is controversial to the extent that it is used to prove a causal relationship between the families' and the teachers' literacy practices, on the one hand, and the students' literacy practices, on the other hand. The SEMs allowed us to formalise a model that collects the different causal chains established as hypotheses in our study to explain literacy. From this analysis, we confirmed the higher capacity of causal explanation of children's practices on the basis of their teachers' practices (as opposed to those of the families). The estimation procedures allow 'to eliminate' certain factors from the list of hypothesised causes (Barringer, Eliason, \& Leahey, 2013). In our study, the SEM model allowed eliminating the relationship between students' and teachers' personal and instructional literacy practices with school ownership.

The comparative analysis of the qualitative data (CQA) reinforces the counterfactual strategy provided by the SEMs. Researchers have employed comparison strategies between cases to draw the differences (bottom-up) and common elements (top-down) (Teddlie \& Tashakkori, 2010). In our study, the CQA has challenged the relationship between the SES and the families' and the students' literacy practices. In addition, the CQA stressed the relationship between the literacy practices of the families and their children's, thus reducing the effect granted to school literacy practices. The CQA reinforced the causal relationship between children's practices and families' practices, since these data underscore the social practice nature of literacy and the way in which these practices take on certain social values according to the families' literacy practices. The CQA allowed us to examine possible causal inferences through the reflections in the interviews, the observations undertaken by the researchers in the different spaces, and the drawings and mappings made by the participants.

\section{QUAN $\rightarrow$ qual diffraction}

The CQA findings present a perspective that differs in some respects from those obtained in the SEM. The use of mixed methods generates diffraction in the interpretations obtained from the quantitative and the qualitative 
perspectives. The SEM granted the SES little capacity to explain children's literacy practices. In contrast, from the CQA, children's literacy practices are interpreted on the basis of the literacy practices of families with different SESes. The cases analysed in the CQA demonstrate that families within the same school and who share the same SES develop different literacy practices. The SEM gives teachers' literacy practices a higher capacity to explain children's practices than the one given to families. However, the CQA accounts for the differences in the children's literacy practices, preferably, on the basis of the social values provided by the families. Moreover, the SEM has shown a relationship between the cultural consumption of the families and the SES. Nevertheless, the CQA revealed that the consumption patterns of material and digital resources in the home are similar across all the SES levels. The use of these resources can be explained on the basis of the different social values given to literacy in the families, independently from their SES.

\section{Limitations}

The integration of quantitative and qualitative data poses some limitations, which are derived from the very nature of the data. The QUANT Component relies on the use of discontinuous data obtained from a Likert scale, which refer to the literacy events carried out by the subjects. Conversely, the qual Component uses polysemic data, which are obtained from very diverse sources (photographs, drawings, mappings, audio and video recordings, etc.), and which demonstrate the social value given to literacy practices. The interpretation of the quantitative data has been situated at the level of statistical decisionmaking, whereas the interpretation of qualitative data has followed a critical discourse analysis approach. The integration between the two perspectives results in contradictions in the interpretation of the obtained results. These contradictions entail a new challenge in literacy research and warn about the complexity of this topic. Diffraction analysis could be an alternative to address issues such as literacy through mixed methods.

Second, the establishment of causal inferences without using experimental designs raises controversy in the social sciences domain. The use of structural equation methods has been considered an acceptable alternative given the impossibility to address particular problems using experiments, as is the case with literacy. The use of CQA as a strategy to establish casual inferences has had a limited application in qualitative research. Consequently, the combination of SEM and CQA to obtain causal inferences causes some uncertainty. Our research has tried to illustrate the way in which causal inferences could be established by integrating the results obtained through both methodologies.

\section{Conclusions}

This study highlights the necessity to study the processes of integration and diffraction that establish causal inferences in depth. The convergence of two different approaches to construct causal inferences is a theoretical and methodological challenge at present. The complexity of the set-out aims justifies that this research has explored new methodological ways that allow studying literacy in depth.

The construction of causal inferences through mixed research methods requires quantitative and qualitative data to be compared and integrated in order to provide answers to each of the research questions. Our research findings compare and integrate the causal explanations offered by the SEM and the CQA. This comparison allows us to establish similarities and differences between the results using both procedures (Hathcoat \& Meixner, 2017).

The complexity of literacy processes in current society calls for new approaches based on mixed methods that do not limit themselves to describing literacy practices, but that explore the causal relationships between these practices and other economic, social, cultural, and personal variables. 


\section{References}

Barringer, S.N. Eliason, S.R., \& Leahey, E. (2013). A history of causal analysis in the Social Sciencies (pp. 9-26). In Morgan, S.L. (Ed.) Handbook of Causal Analysis for Social Research, pp.91-112. Springer. https://doi.org/10.1007/978-94-007-6094-3_2

Barton, D. \& Lee, C. (2013). Language online. Investigating digital texts and practices. Routledge.

https://doi.org/10.4324/9780203552308

Bezemer, J. \& Kress, G. (2016). Multimodality, learning and communication. A social semiotic frame. https://doi.org/10.4324/9781315687537

Bloome, D. (2012). Classroom ethnography. En M. Grenfell, D. Bloome, C. Hardy, K. Pahl, J. Rowsell y B. Street, Language, ethnography, and education. Bridging new literacy studies and Bourdieu (pp. 7-26). Routledge.

Borrero, N. \& Yeh, C. (2010). Ecological English language learning among ethnic minority youth. Educational Researcher, 39(8), 571-581. https://doi.org/10.3102/0013189X10389810

Burnett, C. (2014). Investigating pupils' interactions around digital texts: a spatial perspective on the "classroom-ness" of digital literacy practices in schools. Educational Review, 66(2), 192-209. https://doi.org/10.1080/00131911.2013.768959

Burnett, V. (2016). Being together in classrooms at the interface of the physical and virtual: implications for collaboration in on/off-screen sites. Learning, Media and Technology, 41(4), 566-589.

https://doi.org/10.1080/17439884.2015.1050036

Burnett, C., Davies, J., Merchant, G., \& Rowsell, J. (Eds.) (2014). New literacies around the globe: polcy and pedagogy. Routledge. https://doi.org/10.4324/9781315867311

Burnett, C. \& Merchant, G. (2018). Literacy-asevent: accounting for relationality in literacy research. Discourse: Studies in the cultural politics of education (pre-print). https://doi.org/10.1080/01596306.2018.1460318

Byrne, B.M. (2010). Structural equation modeling with AMOS. Basic concepts, applications and programming. 2nd edition. Routledge.
Clark, V. L. P., \& Ivankova, N. V. (2016). Mixed Methods Research: A Guide to the Field. Thousand Oaks, California. https://doi.org/10.4135/9781483398341

Compton-Lilly, C. \& Green, S. (Eds.) (2011). Bedtimes stories and book reports: connecting parent involvement and family literacy. Teachers College Press.

Davies, J. \& Merchant, G. (2009). Web 2.0 for schools: Learning and social participation. Peter Lang.

Dicks, B., Soyinka, B., \& Coffey, A. (2006). Multimodal ethnography. Qualitative Research, 6(1), 77-96. https://doi.org/10.1177/1468794106058876

Duursma, E., Meijer, A., \& De Bot, K. (2017). The impact of home literacy and family factors on screen media use among Dutch preteens. Journal of Child and Family Studies, 26(2), 612-622. https://doi.org/10.1007/s10826-016-0584-5

Escott, H. \& Pahl, K. (2019). Learning from Ninjas: young people's films as a lens for an expanded view of literacy and language, Discourse: Studies in the Cultural Politics of Education, $\quad 40(6), \quad 803-815$. https://doi.org/10.1080/01596306.2017.1405911

Fairclough, N. (2003). Analysing discourse. Textual analysis for social research. Routledge. https://doi.org/10.4324/9780203697078

Fielding, N. (2012). Triangulation and mixed methods designs: Data integration with new research technologies. Journal of Mixed Methods Research, 6(2), 124-136. https://doi.org/10.1177/1558689812437101

Flecha, R. (2014). Using Mixed Methods From a Communicative Orientation: Researching With Grassroots Roma. Journal of Mixed Methods Research, 8(3), 245-254. https://doi.org/10.1177/1558689814527945

Flick, U. (2009). An introduction to qualitative research: Theory, method and applications. Sage.

Gee, J.P. (2015). Literacy and education. Routledge. https://doi.org/10.4324/9781315739571

Gil Flores, J. (2013). Measuring primary school children's family socioeconomic status. Revista de Educación, 362, 298-322. 
https://doi.org/10.4438/1988-592X-RE-2011362-162

Gillen, J. (2014). Digital literacies. Routledge. https://doi.org/10.4324/9781315813530

Gillen, J. \& Cameron, C. (Eds.) (2010). International Perspectives on Early Childhood Research: A Day in the life. Palgrave Macmillan.

Gillen, J. \& Kucirkova, N. (2018). Percolating spaces: Creative ways of using digital technologies to connect young children's school and home lives. British Journal of Educational Technology, 49(5), 834-846. https://doi.org/10.1111/bjet.12666

Guzmán-Simón, F., Moreno-Morilla, C., \& GarcíaJiménez, E. (2018). Analysis of Different Views and Conceptualizations of the Literacy Practices of Pupils, Families, and Teachers in Costa Rican Primary Education. Journal of Research in Childhood Education, 32(3), 268-282. https://doi.org/10.1080/02568543.2018.1464527

Hackett, A. (2017). Parents as researchers: collaborative ethnography with parents. Qualitative Research, 17(5), 481-497. https://doi.org/10.1177/1468794116672913

Hackett, A. \& Somerville, M. (2017). Poshuman literacies: young children moving in time, place and more-than-human worlds. Journal of Early Childhood Literacy, 17(3), 374-391. https://doi.org/10.1177/1468798417704031

Harding, D.J. and Seefeldt, K.S. (2013). Mixed methods and causal analysis. In Morgan, S.L. (Ed.) Handbook of Causal Analysis for Social Research (pp.91-112). Springer. https://doi.org/10.1007/978-94-007-6094-3 6

Hathcoat, J. D., \& Meixner, C. (2017). Pragmatism, Factor Analysis, and the Conditional Incompatibility Thesis in Mixed Methods Research. Journal of Mixed Methods Research, 11(4), 433-449. https://doi.org/10.1177/1558689815622114

Heath, S.B. \& Street, B.V. (2008). On ethnography. Approaches to language and literacy research. Teachers College Press.

Hemmings, A., Beckett, G., Kennerly, S., \& Yap, T. (2013). Building a Community of Research Practice: Intragroup Team Social Dynamics in Interdisciplinary Mixed Methods. Journal of Mixed Methods Research, 7(3), 261-273. https://doi.org/10.1177/1558689813478468
Hill, S. (2010). The millennium generation: Teacher-researchers exploring new forms of literacy. Journal of Early Childhood Literacy, 10(3), 314-340.

https://doi.org/10.1177/1468798410372820

Howe, K. R. (2012). Mixed Methods, Triangulation, and Causal Explanation. Journal of Mixed Methods Research, 6(2), 89-96. https://doi.org/10.1177/1558689812437187

Hull, G. \& Schultz, K. (2002). Connecting schools with Out-of-School worlds. Insights from recent research on literacy in non-school settings. In G. Hull \& K. Schultz (Eds.) School's Out! Bridging Out-of-School Literacies with Classroom Practice (pp. 32-57). Teachers College Press.

Hvit, S. (2015). Literacy events in toddler groups: preschool educators' talk about their work with literacy among toddlers. Journal of Early Childhood Literacy, 15(3), 311-330. https://doi.org/10.1177/1468798414526427

Ivankova, N. V., \& Plano Clark, V. L. (2018). Teaching mixed methods research: using a socioecological framework as a pedagogical approach for addressing the complexity of the field. International Journal of Social Research Methodology, 21(4), 409-424. https://doi.org/10.1080/13645579.2018.1427604

Kress, G. (2010). Multimodality. A social semiotic approach to contemporary communication. London and New York: Routledge. https://doi.org/10.4324/9780203970034

LaRoche, S., Joncas, M., \& Foy, P. (2017). Sample design in PIRLS (2016). In M.O. Martin, I.V.S. Mullis, \& M. Hooper (Eds.) Method and procedures in PIRLS 2016 (pp. 3.1-3.34). Chestnut Hill, Massachusetts: TIMMS \& PIRLS International Study Center.

Mackey, M. (2010). Reading from the feet up: the local work of literacy. Children's Literature in Education, $\quad 41, \quad 323-339$. http://dx.doi.org/10.1007/s10583-010-9114-z

McKim, C. A. (2017). The Value of Mixed Methods Research: A Mixed Methods Study. Journal of Mixed Methods Research, 11(2), 202222. https://doi.org/10.1177/1558689815607096

McTavish, M. (2014). "I'll do it my own way!'”: A young child's appropriation and recontextualization of school literacy practices in 
out-of-school spaces. Journal of Early Chidlhood Literacy, $\quad$ 14(3), 319-344. http://dx.doi.org/10.1177/1468798413494919

Mahoney, J. (1999). Nominal, ordinal, and narrative appraisal in macrocausal analysis. The American Journal of Sociology, 104, 1154-1196. https://doi.org/10.1086/210139

Mahoney, J. (2000). Strategies of inference in small- $N$ analysis. Sociological Methods and Research, 28, 387-424. https://doi.org/10.1177/0049124100028004001

Mahoney, J., Goertz, G., \& Ragin, C. C. (2013). Causal models and counterfactuals. In S. L. Morgan (Ed.), Handbook of causal analysis for social research (pp. 75- 90). Springer.

Marsh, J. (2011). Young children's literacy practices in a virtual world: establishing an online interaction order. Reading Research Quarterly, 46(2), 101-118. http://dx.doi.org/10.1598/RRQ.46.2.1

Mertens, D. M. (2007). Transformative Paradigm. Journal of Mixed Methods Research, 1(3), 212225. https://doi.org/10.1177/1558689807302811

Moreno-Morilla, C., Guzmán-Simón, F., \& GarcíaJiménez, E. (2017). Los hábitos de lectura y escritura en los estudiantes de Educación Primaria: un análisis dentro y fuera de la escuela. Porta Linguarum, II (monográfico), 117-137.

Moreno-Morilla, C., García-Jiménez, E., \& Guzmán-Simón. E (2018). Relationship between literacy events and low socio-economic status in primary education: analysis of different views of Spanish-speaking pupils, families, and teachers. RICERCAZIONE, 10(2), 149-169. https://doi.org/10.32076/RA10210

Moreno-Morilla, C., Guzmán-Simón, F., \& GarcíaJiménez, E. (2019). Literacy practices of primary education children in Andalusia (Spain): A familybased perspective. British Educational Research Journal, 45(1), 117-136. https://doi.org/10.1002/berj.3487

Natasi, B., Hitchcock, J. y Brown, L. (2010). An inclusive framework for conceptualizing mixed methods design typologies: Moving toward fully integrated synergistic research models. In A. Tashakkori y C. Teddlie (Eds.), Handbook of mixed methods in social \& behavioral research (pp. 305-338). Sage. https://doi.org/10.4135/9781506335193.n13
Neuman, S.B. \& Celano, D. (2001). Access to print in low-income and middle-income communities: an ecological study of four neighborhoods. Reading Research Querterly, 36(1), 8-26.

Pahl, K. \& Allan, C. (2011). 'I don't know what literacy is': Uncovering hidden literacies in a community library using ecological and participatory research methodologies with children. Journal of Early Childhood Literacy, 11(2), 190-213. http://dx.doi.org/ $10.1177 / 1468798411401864$

Pahl, K. \& Rowsell, J. (2012). Literacy and Education. Understanding the New Literacy Studies in the Classroom. Sage. https://doi.org/10.4135/9781473915237

Patton, M. Q. (2002). Qualitative research and evaluation methods (3rd ed.). Sage.

Pellegrini, A. \& Galda, L. (2003). The Development of School-Based Literacy: A Social Ecological Perspective. Routledge.

Pezoa, JP., Mendive, S., \& Strasser, K. (2019). Reading interest and family literacy practices from prekindergarten to kindergarten: Contributions from a cross-lagged analysis. Early Childhood Research Quarterly, 47(2), 284-295. https://doi.org/10.1016/j.ecresq.2018.12.014

Plano Clark, V. L., \& Ivankova, N. V. (2016). Mixed Methods Research: A Guide to the Field. Sage. https://doi.org/10.4135/9781483398341

Poveda, D. \& Sánchez Carrión, J.J. (2010). Las prácticas y estilos de literacidad de los adolescentes fuera de la escuela: una exploración cuantitativa de las relaciones entre literacidad, escolarización y origen familiar. Sociolinguistic Studies, $\quad 4(1), \quad 85-114$. https://doi.org/10.1558/sols.v4i1.85

Rowsell, J. \& Pahl, K. (2007). Sedimented identities in texts: Instances of practice. Reading Research Quarterly, 42(3), 388-404. http://dx.doi.org/10.1598/RRQ.42.3.3

Rowsell, J. \& Pahl, K. (Eds.) (2015). The Routledge Handbook of Literacy Studies. Routledge. https://doi.org/10.4324/9781315717647

Sorde Marti, T., \& Mertens, D. M. (2014). Mixed Methods Research With Groups at Risk: New Developments and Key Debates. Journal of Mixed Methods Research, 8(3), 207-211. https://doi.org/10.1177/1558689814527916 
Tashakkori, A., \& Creswell, J. W. (2007). The New Era of Mixed Methods. Journal of Mixed Methods Research, 1(1), 3-7. https://doi.org/10.1177/1558689807309913

Tashakkori, A. \& Teddlie, C. (2003). The past and future od mixed methods research: from data triangulation to mixed models design. In A. Tashakkori \& C. Teddlie (Eds.), Handbook of Mixed Method in Social and Behavioral Research (pp. 671-702). Sage.

Teddlie, C., \& Tashakkori, A. (2010). Overview of contemporary issues in mixed methods research. In A. Tashakkori \& C. Teddlie (Eds.), SAGE Handbook of Mixed Method in Social \& Behavioral Research (pp. 1-41). Sage. https://doi.org/10.4135/9781506335193.n1

Tusting, K. \& Barton, D. (2005). Communitybased local literacies research. In R. Beach, J. Green, M. Kamil, \& T. Shanahan (Eds.),
Multidisciplinary perspectives on Literacy Research (pp. 243-263). Hampton Press.

Uprichard, E., \& Dawney, L. (2019). Data Diffraction. Journal of Mixed Methods Research, 13(1), 19-32. https://doi.org/10.1177/1558689816674650

van Leewen, T. (2005). Introducing social semiotics. Routledge. https://doi.org/10.4324/9780203647028

Woumans, E., Ameloot, S., Keuleers, E., \& Van Assche, E. (2019). The relationship between second language acquisition and nonverbal cognitive abilities. Journal of Experimental Psychology: General, 148(7), 1169-1177. http://dx.doi.org/10.1037/xge0000536

Yin, R.K. (2014). Case Study Research Design and Methods (5th ed.). Sage.

\section{Authors / Autores \\ Moreno-Morilla, C. (celia.moreno@dedu.uhu.es) (D) 0000-0003-0566-4319 \\ Celia Moreno-Morilla is an assistant professor in the Department of Pedagogy of the University of Huelva. Her career as a teacher and researcher is located in the Department of Research and Diagnostic Methods in Education at the University of Seville, where she completed her doctoral studies in 2019. Her interest in the study of literacy led her to internationally renowned centers, like the "Center for the Study of Literacy" or the "Lancaster Literacy Research Center". She is currently participating in the research project "Improvement of Multimodal Literacy in Children (3-8 Years): Development of an Integrative Model in Areas with Social Transformation Needs" (PID2019-104557GB-I00). This researcher is the author of several articles about literacy published in high-impact international journals.}

\section{Guzmán-Simón, F. (fernandoguzman@us.es) (iD 0000-0001-7189-1849}

Fernando Guzmán-Simón is an associate professor in Spanish Language and Literature Teaching at the University of Seville (Spain). He has published several research articles on the assessment of academic writing in Spanish. At present, his research is framed in a broader research project about the development of Literacy in Early Childhood and Primary School. This project aims to describe the literacy event of students and their families, and how they create new spaces of social interaction. It seeks to identify and analyze the conflicts generated in the process of school literacy among the different communities and to elaborate an explanatory model of the low development of literacy in lowincome families.

\section{García-Jiménez, E. (egarji@us.es) Đ0000-0002-5885-8267}

Eduardo García Jiménez is full profesor in the Department of Research Methods at University of Seville. He is interested in reviewing new research approaches and techniques for collecting and analyzing qualitative and quantitative data, and incorporating them into the study of literacy, has participated in projects on the linguistic communication compentece from the New Literacy Studies perspective, and explored causal inferences in qualitative and quantitative research methods. 


\section{RELIEVE}

Revista ELectrónica de Investigación y $\mathbf{E V}$ aluación Educativa E-Journal of Educational Research, Assessment and Evaluation

[ISSN: 1134-4032]

\section{(c) (i) (3)}

Esta obra tiene licencia de Creative Commons Reconocimiento-NoComercial 4.0 Internacional. This work is under a Creative Commons Attribution 4.0 International license. 